\title{
JózSEF SZABAdFalvi*
}

\section{From Original Sources-Neo-Kantian Legal Philosophical Thinking in Hungary}

The traditions of Hungarian legal philosophy followed the various periods of the Continental legal philosophical thinking until the mid-20th century. The oeuvres of the most significant legal philosophers are not restricted to the interpretation of the achievements of the more developed legal cultures, but are also reflected in independent theoretical efforts. In addition, Hungarian neo-Kantian theorists have created a number of works acknowledged internationally.

Among these studies, Juristische Grundlehre ${ }^{1}$ by Felix (Bódog) Somló and Rechtssoziologie $e^{2}$ by Barna Horváth distinguish themselves, being frequently cited in international legal literature and available in renowned libraries across Europe. In addition, a number of other studies written by the above-mentioned authors in the German language must be mentioned. In addition, a number of references by European contemporaries, especially to Julius (Gyula) Moór's works, appeared in publications between the two World Wars as well as in the years afterwards.

Somló's monograph, first published in 1917, was reissued by the same publisher ${ }^{3}$ ten years later, due to its favourable reception and general interest, and this was then followed by a third reprint by Scientia Verlag in $1973 .{ }^{4}$ Horváth's Rechtssoziologie rivals its great predecessor's reputation. The monograph, published in 1934 by the aforementioned wellknown publisher, attracted the attention of scholars both in Europe and overseas. This is proved by the fact that the first part of Rechtssoziologie, complemented with other studies which had been published earlier in German, was republished by Buncker and Humbolt in 1971.5 The Theory of Civil Law and Society by Ágost Pulszky, the founder of Hungarian legal positivism, published in London in 1888, is also to be mentioned here. ${ }^{6}$ His work, comprised of his university lectures, is considered the peak of his efforts to create an independent theory, which may be regarded as one rivalling any other contemporary achievement of the kind.

These papers and their afterlives prove that there exists a segment of legal philosophical tradition in Hungary that is renowned even outside the country's borders in professional circles. For the sake of Hungarian jurisprudence, all the significant achievements of

* Professor of Law, University of Debrecen, Faculty of Law, Department of Philosophy and Sociology of Law, H-4010 Debrecen, P.O. Box 81.

E-mail: szabadfalvi.jozsef@law.unideb.hu

1 Somló, F.: Juristische Grundlehre. Leipzig, 1917.

${ }^{2}$ Horváth, B.: Rechtssoziologie. Probleme der Gesellschaftlehre und der Geschichtslehre des Rechts. Berlin, 1934.

3 Somló, F.: Juristische Grundlehre. Leipzig, 1927.

${ }^{4}$ Somló, F.: Juristische Grundlehre. Aalen, 1973.

5 Horváth, B.: Probleme der Rechtssoziologie. Berlin, 1971.

${ }^{6}$ Pulszky, Á.: The Theory of Civil Law and Society. London, 1888. 
international standards should be made accessible for the world. In this field our great predecessors have provided a good example through providing the world with their evaluations of Hungarian legal philosophical thinking. ${ }^{7}$ The evaluations had, at that time, an orientating effect on contemporary international scientific attitude, and are still regarded worthy of consideration. For the past two decades great efforts have been made to rediscover the traditions of Hungarian jurisprudence. A number of essays, monographs, volumes of studies, and reprints of the oeuvres of legal philosophers representing the major trends have been published, which has resulted in the revaluation of the "bourgeois" legal philosophy, to use the Marxist term that had been forgotten before the change of regime $(1989 / 90) .{ }^{8}$ Today all of these possibilities and sources of information are available for those interested in legal philosophy.

Hereafter I wish to call the reader's attention to a series of books that aims to make public the achievements of Hungarian legal philosophy published in foreign languages in the early 20th century. The title of the series is "Philosohiae Iuris", edited by Csaba Varga, with its sub-series in foreign languages called "Excerpta Historica Philosophiae Hungaricae Iuris", which contain essays representing perhaps the most prosperous period of Hungarian legal philosophy, partly as faximile reprint as well as the first edited publication of manuscripts.

In the volumes published so far the reader can find essays mostly in German, but also in French, English and Italian, which are supplemented with short biographies, lists of publications, and lists of essays introducing the oeuvres, and in the end, lists of names and, in two cases, of legal sources. All reflect a unified editorial concept. ${ }^{9}$

Schriften zur Rechtsphilosophie ${ }^{10}$ by Felix Somló (1873-1920), professor of Nagyvárad Academy of Law as well as of the Faculty of Law at Kolozsvár University, was published as the first in this series in 1999. This edition includes the essays and book reviews written and published between 1907 and 1914 by the professor of law, who achieved international fame for Hungarian legal philosophy in the early 20th century. Another point of interest of the book is that it contains the first critical reviews by Joseph Kohler, Leonidas Pitamic and Robert Redslob in 1917-1918, as well as a preface written by Gyula Moór in Somló's Gedanken zu einer Ersten Philosophie, ${ }^{11}$ a fragmented posthumous work from 1926, which established his legal value principle. The volume also includes Moór's preface to the second edition of Juristische Grundlehre in 1927.

7 See Somló, F.: Die neuere ungarische Rechtsphilosophie. Archiv für Rechts- und Wirtschaftsphilosophie, 1 (1907-1908) 315-323.; Horváth, B.: Die ungarische Rechtsphilosophie. Archiv für Rechts- und Wirtschaftsphilosophie, 24 (1930) 31, 37-85.

${ }^{8}$ See about contemporary Hungarian legal philosophical thinking In: Szabadfalvi, J: Transition and Tradition. Can Hungarian Traditions of Legal Philosophy Contribute to Legal Transition? Rechtstheorie, 33 (2002) 2-4, 167-185. [Krawietz, W.-Varga, Cs. (eds): On Different Legal Cultures, Premodern and Modern States, and Transition to the Rule of Law in Western and Eastern Europe. II. Sonderheft Ungarn.] Revaluation of Hungarian Legal Philosophical Tradition. Archiv für Rechts- und Sozialphilosophie (ARSP), 89 (2003) 2, 159-170; Varga, Cs.: Philosophysing on Law in the Turmoil of Communist Take-over in Hungary (Two Portraits, Interwar and Post-war). In: Leszkiewicz, M. (ed.): The 2005 ALPSA Annual Publication of the Australian Legal Philosophy Students Associations. Brisbane, 2005, 82-94.

9 The volumes of this series of books are accessible on www.stephanus.hu website.

10 See Somló, F. in: Varga, Cs. (ed.): Schriften zur Rechtsphilosophie. Budapest, 1999.

11 Somló, F.: Gedanken zu einer Ersten Philosophie. Berlin-Leipzig, 1926. 
These are less known but nevertheless significant essays if the evaluation of an oeuvre is considered. While the writings in the appendix offer the evaluation of Somlós work after his neo-Kantian turn, the previous studies and reviews provide an introduction to the break with the sociological-positivist traditions of a Julius Pikler student following Spencer, as well as his acceptance of the neo-Kantian paradigm. Important milestones in this process are his study on the new Hungarian legal philosophy of positivism (Die neuere ungarische Rechtsphilosophie) and his essay on the application of law (Die Anwendung des Rechts), as well as his lecture, reflecting his change of paradigm, which was delivered at a conference on legal philosophy in Germany in 1911 (Das Verhältnis von Soziologie und Rechtsphilosophie, insbesondere die Förderung der Rechtsphilosophie durch die Soziologie). The lecture was based on the definition of law and the examination of the justness of law as two fundamental issues in the philosophy of law. The latter question is discussed in more detail in his study on the value standards of law (Massstäbe zur Bewertung des Rechts) published in 1909. In his investigation of the right law, moral values are considered as the most appropriate tools for evaluating law as the norm of act.

The publication of these studies provides an opportunity for those interested in gaining insight into the revival of Hungarian legal philosophy in the decade after the turn of the 19th-20th centuries. The neo-Kantian philosophy being established in those years on the Continent surpassed the traditional theories of natural law and legal positivism as well as the historical view. Jurisprudence, seeking new paths, emphasized a new approach to law through modern methodology and value theory, and Somló had a laudable role in this process. His works created a possibility to abolish the previous delay in development and to establish in Hungary the then leading neo-Kantian legal philosophy. This all resulted in his being considered the number one representative of Hungarian legal philosophy for decades. The essays included in this volume may help us to understand the process. Hungarian legal philosophy can be proud of the fact that Somló, alongside Rudolf Stammler, Gustav Radbruch, Hans Kelsen and Alfred Verdross, is considered to be among the great representatives of the European neo-Kantian philosophy of law.

The second volume of the series, published in 2002, is devoted to Abriss eines realistischen rechtsphilosophischen Systems ${ }^{12}$ written by István Losonczy (1908-1980), a reserved, rather eccentric figure of legal philosophy in Hungary, who had comprehensive knowledge of not only jurisprudence but of natural and medical sciences as well. Besides the "realistic" legal philosophy promised in the title, the book also contains, in the appendix, a study published in a professional journal. Losonczy wrote this study upon Alfred Verdross' request at the turn of 1948-1949 to be published in Österreichische Zeitschrift für öffentliches Recht, however, it was not issued due to the socio-political changes at that time. This study was originally published under the title Über die Möglichkeit und den Wissenschaftscharakter der Rechtswissenschaft in 1937. Here the author discussed issues on jurisprudence as a field of science, including mainly problems of theories of existence, the theory of knowledge, and methodology. The editor of the series, as a former student of Losonczy, may have appreciated this study the most, since it allowed the young jurist's philosophical oeuvre to be reconstructed starting from the 1930s.

The essays included in the volume allow insight to be gained into the attempt to surpass the neo-Kantian paradigm. Losonczy expressed his concept of law against Kelsen's "pure

12 See Losonczy, I. in: Varga, Cs. (ed.): Abriss eines realistischen rechtsphilosophischen Systems. Budapest, 2002. 
theory of law"-representing a real challenge for his contemporaries. According to Losonczy's theory, law is a phenomenon including logical, explicative and normative elements, which seems to be evident regarding jurisprudential research, originating in statute law. By refusing Kelsen's dogmas, he stands for applying a complex or in other words a "synthetic method", which is based on the recognition of rules that constitute law. In his view, "purified" synthetic methodological theories have already been created, among which he emphasizes the theories represented by Barna Horváth, Albert Irk, and Julius (Gyula) Moór, as well as Erik Kaufmann, Wilhelm Sauer and Alfred Verdross in the German scholarly literature. It is a great loss for the Hungarian philosophy of law that after 1949 Losonczy, as well as some of his contemporaries such as József Szabó and István Bibó, or the few years younger Kornél Solt (Scholz), were not allowed to continue their research. They either had to change careers or were forced into inner exile, or, in the worst case, they were imprisoned. Losonczy, for the sake of Hungarian jurisprudence, was able to continue his activity as a criminal lawyer.

The most extensive edition was published in 2006, Schriften zur Rechtsphilosophie, ${ }^{13}$ a volume of studies by Julius (Gyula) Moór (1888-1950), professor of legal philosophy at the universities of Szeged and Budapest. This is a book of 500 pages in excellent faximile quality, comprising seventeen studies in German, two in Italian and one in French, published between 1922 and 1943, representing his whole oeuvre in a comprehensive manner. Moór insisted on making his writings, in which he primarily expressed his views on the philosophy of law, available for the international community of scholars. In this respect, he can be regarded as the most internationally-aware author in the Hungarian literature of legal philosophy in the first half of the 20th century. Unfortunately, a monographic representation of his synthesis on legal philosophy is missing, to the great disappointment of this field of study.

The collected and published essays provide a retrospective overview on the work of the most beloved student of Somló, the number-one personality of legal philosophy in Hungary between the two World Wars, who was in the early 1920s rightly called by his famous colleague Barna Horváth the creator of the "new Hungarian philosophy of law" as well as its "representative man". Moór's philosophy of law was fundamentally determined by his acceptance of the neo-Kantian view, which he openly declared as a starting point in philosophy. However, he admitted that neo-Kantianism with its numerous trends allows very different philosophical conclusions to be drawn.

His system of legal philosophy (fundamental doctrine of law, sociology of law, legal axiology, and methodology of jurisprudence) was characterized by a complex view on posing problems. It was not by chance that he considered his own view to be among "comprehensive philosophical views of law", which involves an overall concern with "eternal" issues of jurisprudence. Moór was inspired to create a system based on the most significant literature of jurisprudence, drawing conclusions from the mistakes of previous doctrines, and exempt from one-sided extremes.

Moór was from the beginnings of his career an advocate of neo-Kantian philosophy who, considering the distinction between reality and value to be fundamental, attempted to settle the relationship between these two spheres. A cornerstone of his reasoning was his doctrine on the dual character of law, which emphasized duality between reality and value in law. In his view, law is a complex phenomenon composed of elements belonging either to the world of existence or to that of values. This concept was first described in the starting

13 See Moór, J. in: Varga, Cs. (ed.): Schriften zur Rechtsphilosophie. Budapest, 2006. 
study of the volume titled Macht, Recht, Moral (1922), which is at the same time a brilliant summary of his basic doctrine on law. Another study, titled Das Logische im Recht (1928), summarizing his fundamental views on legal dogmatics and methodology, was included in the volume as his leading work from the 1920s. Among the works representing the 1930s, a study Reine Rechtslehre, Naturrecht und Rechtspositivizmus (1931) published in "KelsenFestschrift" can be read, which provides interpretation and criticism on the most significant system of legal theory of the 20th century. Furthermore, Reine Rechtslehre: Randbemerkungen zum neuesten Werk Kelsens (1935) is to be mentioned as the first evaluation of Kelsen's synopsis ${ }^{14}$ in Hungary, in which Moór expressed his opinion as a contemporary of equal standing to Kelsen, professor in Vienna.

As part of the notional analysis of law, Recht und Gewohnheitsreicht (1934) discussing the issue of common law is also included in the volume, as well as the following studies: Das Wesen der Philosophie nach Pauler (1936) on the issues of the philosophy of science, Creazione e applicazione del diritto (1934), discussing the problems of creating and applying law, and Öffentliches und privates Recht (1938) and Das Rechtssystem (1939) discussing his special point of view on the system of law. Das Problem des Naturrechts (1935), one of the works of key importance in that decade, is a summary of Moór's "negative or limitative natural law". In his study, similarly to most contemporary Hungarian neo-Kantian philosophers of law, he expressed his opposition to Kelsen's view, which attempted to simplify reality, as well as to the extremes of legal positivism.

The first study in the series from the 1940s is Der Wissenschafts-Charakter der Jurisprudenz (1940) discussing issues of theory and methodology of science, followed by a study on the problems of legal loopholes, titled Sulla questione delle lacune nel diritto (1941). Recht und Gesellschaft (1942) discussed causal connections in detail. The closing study in the volume, Was ist Rechtsphilosophie? (1943) is Moór's last comprehensive work written in German, which might as well be considered as a final synopsis of his legal philosophical views. In Moór's view pointing towards a synthesis, a decisive turn occurred during the 1930s and in the early 1940s, and a synthesis of characteristic changes appeared, mainly in the philosophical basis of his philosophy of law. This new kind of view represented a new trend, which had developed from a synthesis of neo-Kantian and neo-Hegelian views, whose legal philosophical consequences were not subsequently elaborated in detail.

This brief overview does not provide the opportunity to describe and emphasize the importance of each study written by Moór. Nevertheless, it seems a pity that the volume only includes a short resume of two important studies [Metaphysik und Rechtsphilosophie (1929) and Soziologie und Rechtsphilosophie (1934)]. Mainly this latter study could have represented the progress that had occurred in Moór's oeuvre resulting in his describing law as a phenomenon in the empire of "valuable reality". In spite of all this, the volume represents this diverse life's work in a sufficient way. The author of the review aims to call the attention of the reader to another issue which with Moór was concerned in the 1920s, namely the problem of pacifism and anarchy. He published a book and a study in this topic in German. ${ }^{15}$

14 Kelsen, H.: Reine Rechtslehre. Leipzig-Wien, 1934.

15 Moór, J.: Zum ewigen Frieden. Grundriss einer Philosophie des Pazifismus und des Anarchismus. Leipzig, 1930; Das Wesen des Pazifismus und die darin enthaltenen ethischen, logischen und soziologischen Probleme. In: Studi Filosofico-Giuridici dedicati a Giorgo del Vecchio bel XXV anno di insegnamento (1904-1929). II. Società Tipografica Modenese, Antica Tipografica Soliani, Modena, 1931, 146-159. 
A unique piece in the series is the volume The Bases of Law / A jog alapjai ${ }^{16}$ by Barna Horváth (1896-1973), professor of philosophy of law at Szeged and Kolozsvár universities. A point of interest in this publication is that although it was originally written in English around 1947-1948, it is also available in Hungarian translation. A brief biography and a list of references in English are supplemented with two further studies by István H. Szilágyi, who has long been concerned with Horváth's oeuvre. These essays give an insight into the author's career and also provide information on the mutual intellectual influence of Horváth and István Bibó, his former student. The published manuscript bears a further point of interest in that an important element concerning the oeuvre was focused on through giving an answer to the question of how Horvath reconsidered his system of the theory of law prior to his emigration at the end of 1949.

The originality of Horváth's legal philosophy, which he preferred to call "pure legal sociology", considering Kelsen's terminology, lies in his synoptic attitude and the closely related processual legal view, which was discussed in detail in his Rechtssoziologie of 1934 and in $A$ jogelmélet vázlata (Outlines of legal theory), ${ }^{17}$ published three years later. The originality of the theory is included in harmonizing two paradigms that were in contradiction within the contemporary legal philosophy. The parallel effectiveness of the continental neoKantian view and the pragmatic-empirical attitude of Anglo-Saxon origin proved to be a pioneering idea not only in Hungarian but in European legal thought as well. Horváth, through applying the synoptic method, provides a completely original interpretation of one of the fundamental issues of neo-Kantian legal philosophy, namely the relationship between value and reality. He evolved his method from the essence of the activity of lawyers and modelled it as the scheme of thoughts in the judge's head. The processual view, connected to the synoptic one, claims that law is not simply a norm but a theoretical norm of behaviour and the related actual behaviour, which is nothing else but the procedure. A continuous coordination (of synoptic character) between a legal case and the legal norm creates the procedural process. The significance of Horváth's oeuvre lies in the fact that he created new perspectives for further development in the national legal theory through combining the familiar German-Austrian ties with views on jurisprudence in the English-speaking world.

The novelty of the recently published volume lies in the fact that Horváth, possibly thinking of emigration, chose the English language to summarize (practically word for word, as István H. Szilágyi pointed out) the view that he had elaborated a decade earlier. At the same time he reacted to the critical remarks included in István Bibó's-his former student and by that time colleague-Zwang, Recht, Freiheit (1935). However, it is problematic why only a decade later he, an author completing research in the history of theory, sociology and the history of law, considered a return to legal theoretical roots an issue of great importance. After his emigration two dozen reviews and articles were published, mostly in English. The period of more than two decades that he spent in the USA brought about only one important paper in English, published in Australia, which revealed his attempt to think over the synoptic method. This work resulted in high professional interest and international discussion and aimed to describe the theory of "law field" in law. The underlying idea of this view was a change in the concept of the physical world due to the findings of modern physicists (Einstein and Maxwell). The theory of law field is not an elaborated view, it is

16 See Horváth, B. in: Varga, Cs. (ed.): A jog alapjai (The Base of Law). Budapest, 2006.

17 Horváth, B.: A jogelmélet vázlata (Outlines of Legal Theory). Szeged, 1937. 
rather an exciting theoretical experiment worth reconsidering. ${ }^{18}$ In addition to this, in the 1950s he began to translate into English his monograph Angol jogelmélet (English legal theory), ${ }^{19}$ which was published in Hungarian in 1943, but was unable to complete it. The only professional recognition for him was the publication of the previously mentioned Probleme der Rechtssoziologie.

It deserves a mention that Horváth's other studies written in foreign languages are to be issued in the near future as part of this series. The three volumes will include writings by Horváth on processual legal theory, the theory of justness and studies published during his years abroad, written mostly in German and English. ${ }^{20}$ These further volumes will make available the entire works of Horváth published in foreign languages.

Finally, the volume Die Schule von Szeged completes the series. ${ }^{21}$ The subtitle (Rechtsphilosophische Aufsatze von István Bibó, József Szabó und Tibor Vas) aims to inform the less-informed reader on those authors whose legal philosophical studies are included in the book. Even today we know little about the "School of Szeged", a community composed of former students of Horváth. ${ }^{22}$ Nevertheless, even if it cannot be compared to the "new Austrian school" marked by Hans Kelsen, Adolf Merkl, and Alfred Verdross, which had a great effect on the European legal philosophical thinking after the turn of the century, still, as the only Hungarian school of jurisprudence, it has a considerable importance in national as well as in international jurisprudence.

The first publications by the members of the school of Szeged, approaching the world of law through the neo-Kantian paradigm represented by their professor, were issued from the mid-1930s. The first part of the volume includes István Bibó's (1911-1979) legal philosophical studies. Under the title Zwang, Recht, Freiheit a summary in German of his major work on legal theory is included, which was printed in 1935 when he was a student of law. ${ }^{23}$ This detailed resume clearly reflects the fact that the young legal theorist attempted to compose his own view even in this early work. In those years each legal philosopher expressed his own views. Bibó carried out this challenging undertaking with a thoroughness and moderation contrary to his age. According to his aim, he wished to grasp the essence of law in the connection between force and freedom.

When elaborating his theory, he adapted two major categories used by Barna Horváth, the idea of synopsis and the term of social objectification. In terms of Bibó's definition, law simultaneously exercises the most objective force and performs the most objective freedom. This two-faced character of law is not a novelty in legal theory and a number of views have emerged emphasizing one or the other of its faces. According to Bibó, this kind of double

18 See Horváth, B.: Field Law and Law Field. Österreichische Zeitschrift für öffentliches Recht, 8 (1957), 44-81.

19 Horváth, B.: Angol jogelmélet (English Legal Theory). Budapest, 1943.

20 Horváth, B.: Schriften zur Rechtsphilosophie. I. 1926-1948: Prozessuelle Rechtslehre; II. 1926-1948: Gerechtigkeitslehre; III. 1949-1971: Papers in Emigration. (hrsg. Csaba Varga), Budapest, 2011 (in preparation).

${ }^{21}$ Varga, Cs. (ed.): Die Schule von Szeged. Rechtsphilosophische Aufsätze von István Bibó, József Szabó und Tibor Vas. Budapest, 2006.

22 See Szabadfalvi, J.: Bibó István és a szegedi iskola (István Bibó and the School of Szeged). In: Dénes, I. Z. (ed.): A szabadság kis körei. Tanulmányok Bibó István életmüvéröl (Small Circles of Liberty. Studies on the Life-Work of István Bibó). Budapest, 1999. 125-152.

${ }_{23}$ Bibó, I.: Kényszer, jog, szabadság (Zwang, Rechts, Freiheit). Acta Litterarum ac Scientiarum Reg. Universitatis Hung. Francisco-Josephinae. Sectio: Juridico-Politica, Tom. VIII. Szeged, 1935. 
tension will provide the real strength of law as objectification. In concluding this study, József Szabó's contemporary review published in German is included, which is a credit to the editor. Szabó, as a contemporary in close connection with Bibó, called the attention of the public opinion to this early achievement of the school of Szeged in a significant legal journal in the year of publication.

Furthermore, two complete studies by Bibó-originally written in French and Germanare included, which provide a thorough analysis on certain minor problems of legal philosophy. It is not by chance that all this is expressed as criticism of the great theory with respect to Kelsen's theory. A study Le dogme "bellum justum" et la théorie de l'infaillibilité juridique (1936) is a critical paper of Kelsen's pure theory of law. In this paper Bibó gives an immanent judgement on the debate-inspiring study, which had been published two years earlier. He is concerned with the infallibility of law, with the problems of obligation, awareness of international law, those of sanctioning acts and with the normative character of Kelsen's method.

In his paper Rechtskraft, rechtliche Unfehlbarket, Souveränität (1937) the author discusses his view regarding legal force, infallibility and sovereignty, through a different method from the pure theory of law, on the infallibility of law and other related issues. The paradigm of neo-Kantian philosophy is again considered, namely the problem of dualism of "Sein" and "Sollen" and its capability to be transmitted. Bibó seems to be sceptical of the views emphasizing a complete separation of the two spheres and he stands for the feasibility of Horváth's synoptic approach.

The second part of the volume is composed of two papers by József Szabó (19091992) and a short summary in German of a study in written in Hungarian. This study is titled Ort und Stelle der Rechtswissenschaft in dem menschlichen Denken (1942), which is an explanation for a wider audience of his new-realistic ("neurealistischen") view being formed at that time. We can read, as one of his complete studies, Wahrheit, Wert und Symbol im Rechte (1943), which was issued, along with the studies of Moór and Horvatth, in the "Ungarn-Heft" of Archiv für Rechts- und Sozialphilosophie discussing contemporary Hungarian legal philosophy. ${ }^{24}$ The main aim of this study was to summarize the theses on jurisprudence previously elaborated only in Hungarian. According to Szabó, a number of neo-Kantian theories emerging from the duality of existence and validity attempted to find a connection between these two spheres of the world in highly different ways. The reason that most attempts were unsuccessful may lie in the fact that existence and validity are not to be found in the objective world but in the subjective one.

Szabó claims, based on the views of theory of knowledge referring back to Hume, that the world of human subjectivity is one where existence and validity, object and norm have a differentiating sense. The deepest roots of law are to be sought in human subjectivity. This idea allows him to trace back the validity basis of law to moral considerations in human consciousness. Psychological considerations play, not by chance, an important role in his theory, as well as the fundamental idea that the world of law is to regarded as a symbol or a system of symbols. The task of jurisprudence is to find the meaning behind symbols. The

24 József Szabó applied the term "new-realistic" to describe his concept of law in the title of a paper published in 1948. See Szabó, J.: Der Rechtsbegriff in einer neurealistischen Beleuchtung. Österreichische Zeitschrift für öffenliches Recht, 1 (1948) 3, 291-311. (A point of interest in the paper is that it is word by word equal to his study "Wahrheit, Wert und Symbol im Rechte" published five years earlier.) 
paper goes into detail about the connection between formalism and justness. Perhaps the most significant feature of Szabó's new-realistic theory is the fact that he could find answers to questions of neo-Kantian philosophy due to his knowledge of philosophy and jurisprudence of the English-speaking countries, which had been inspired by his one-time schoolmaster. Thus in Szabó's theory the views of two great legal cultures are in creative inter-connection. Unfortunately, the author did not have the chance to further elaborate his theory.

The second Szabó paper was originally published in 1974. From Chaos to the Rule of Law, containing his earlier views on jurisprudence, was published in a Festschrift in honour of René Maric. It is to Szabó's merit that, despite his scientific isolation, he was up-to-date in following with attention the international literature in the field, which is reflected in the references.

In the final part of the book, Die Bedeutung der transzendentalen Logik in der Rechtsphilosophie (1935), a work by Tibor Vas (1911-1983)-a former fellow student and friend of Bibó-published by his alma mater is included, which is followed by a review written by József Szabó. Vas in his paper is concerned with the importance of transcendental logics in legal philosophy; nevertheless, he includes his critical remarks as well. In the first part he introduces in detail the Kantian origins of transcendental logic and its progress in neo-Kantian philosophy, including the efforts by the schools of Marburg and Baden. In the second part the application of the transcendental method is examined through the views of the three most significant representatives of neo-Kantian legal philosophy (Stammler, Kelsen and Somló). The author provides criticism regarding all three theories and proves how the terms applied as prerequisites of general validity in law can lead to the application of meta-legal terms of natural law. The methods of jurisprudence will help to solve this problem of considering not only one but two objects of knowledge in law and denying the possibility of a unified knowledge of law; consequently they do not apply a constitutive method but a reflective one. Among the views that are considered as modern in surpassing the transcendental method, he emphasizes Horváth's synoptic view and Gurvitch's idealrealistic method, which consider the dual-objectivity of law. Vas seems to be very consistent in undermining the illusory conviction in the transcendental approach. All this allows him to seriously criticize the neo-Kantian philosophy of law.

Having briefly introduced the current volumes, the author has no other task than to express his wish that the volumes published so far and the ones being or planned to be published will achieve the editor's goal, the international re-discovery of Hungarian legal philosophy. It is the future responsibility of book distributors that this series of publications should become available for their target audience. ${ }^{25}$

25 The first review on the first volume of the series: Funke, A.: Die Definition des Rechts und die Brille auf der Nase der Juristen. Rechtstheorie, 36 (2005) 4, 427-433. 